\title{
Transformacija mita o Edipu u drami Slepac Huga Klausa
}

\author{
Aleksandar S. Đokanović* \\ Univerzitet u Beogradu, Filološki fakultet, Katedra za germanistiku
}

Ključne reči:
mit
Edip
oceubistvo
incest
slepilo
kuga
nuklearna katastrofa
teorija
intertekstualnosti
Ženet

\section{Apstrakt}

Mit o Edipu i u XX veku neiscrpan je izvor inspiracije. Flamanski pisac Hugo Klaus dao je 1985. svoju varijantu čuvenog mita u drami Slepac (Blindeman). Reč je o parodiji na Senekinu dramu Edip na koju se Klaus oslanjao prilikom pisanja svoje verzije. Drama Slepac smeštena je u kontekst XX veka. Radnja se odvija u Gentu nakon nuklearne katastrofe. U pitanju je reinterpretacija originalnog mita u kome grad Tebu zahvata kuga, dok u drami Slepac grad Gent pogađa kuga savremenog doba izazvana nuklearnim ratom. Što se kompozicije drame tiče, Klaus koristi tehniku drame u drami. Preživeli igraju predstavu „Edip“ i tako Klaus povlači paralelu između priče u sadašnjosti i junaka iz pomenutog mita. Svaki lik u drami ima svoj pandan u mitskoj priči i igra dvostruku ulogu. Imena su prepoznatljiva i po tome što počinju istom slovom ili slogom kao u mitu: Omer, Jolanda, Lano, Tite. Klaus se tokom čitave drame poigrava mitom. Tako npr. u njegovoj obradi Jokasta od samog početka zna da je Edip njen sin. Teorijsku podlogu u radu činiće postavke teorije intertekstualnosti Žerara Ženeta. (примьено: 15. марта 2021; прихваћено: 21. јуна 2021)

www.anali.fil.bg.ac.rs

\section{АНАЛИ}

Filološki fakultet Katedra za germanistiku

Studentski trg 3

11000 Beograd, Srbija adjokanovic@gmail.com 


\section{Uvod}

Cilj ovoga rada je da istraži transformacije koje je mit o tebanskom caru Edipu pretrpeo u interpretaciji flamanskog pisca Huga Klausa u drami Slepac. Komad je napisan na podlozi Senekine verzije, ali kombinuje i elemente iz Sofoklove tragedije Car Edip. U radu ćemo uporediti sve tri verzije, primenjujući teoriju intertekstualnosti francuskog teoretičara književnosti Žerara Ženeta. Poseban doprinos Ženeta teoriji intertekstualnosti je u tome što je detaljno istražio i definisao međutekstualne odnose između originalnog dela i njegovih potonjih obrada. U radu ćemo prezentovati postupke koje Ženet identifikuje kod autora koji preoblikuju izvorni tekst i navesti koje od tih postupaka Hugo Klaus primenjuje u pomenutoj drami. Takođe, istražićemo i razloge zbog kojih autor poseže za mitskom građom i ispitati relevantnost antičkog mita u XX veku.

Hugo Klaus (Hugo Claus, 1929-2008) svestrani je i multitalentovani umetnik: pesnik, romanopisac, dramaturg, pozorišni i filmski reditelj i slikar. Opšta odlika njegovog stila jeste literarna $i$ intelektualna igra sa različitim izvorima, mešanje uzvišenog i tragičnog sa banalnim i prostačkim (up. Novaković-Lopušina, 2005: 147). Veoma bitni toposi u njegovom opusu su antički i biblijski motivi. Gotovo čitavo delo Huga Klausa prožeto je antičkim mitovima. Nekada su to samo aluzije, citati i reminiscencije, a najčešće se javljaju transformisani u novo ruho. Antičke motive nalazimo u poeziji, pripoveci Sabljarka (1989) i njegovom magnum opusu, romanu Tuga Belgije (1983), u kojem je opisao lična iskustva odrastanja u kolaboracionističkoj flamanskoj porodici tokom Drugog svetskog rata. Među antičkim mitovima posebno mesto zauzima mit o Edipu. To ne čudi imajući u vidu da je Klaus imao veoma složen odnos sa ocem. Proučavanjem antičkih motiva u holandskoj i flamanskoj književnosti bavi se Paul Klas, flamanski pisac i književni kritičar, čije su značajne studije iz ove oblasti Echo's echo's (Odjeci Ehe, 1988) i De gulden tak (Zlatna grana, 2000). U svojoj doktorskoj disertaciiji De mot zit in de mythe (Izgubljen u mitu, 1984) posebnu pažnju je posvetio referencama na klasične tekstove u delu Huga Klausa.

Incest kao sastavni deo mita o Edipu veoma često se javlja u Klausovom delu: u dramama Nevesta ujutru (1955), Mama, vidi bez ruku! (1959), Slepac (1985), u romanima Lov na divlje patke (1950), Začuđenost (1962), Glasine (1996) i njegovom nastavku Nesvršena prošlost (1998), potom u romanu U vezi sa Dedeom (1963) kao i u njegovoj pozorišnoj verziji Enterijer iz 1971. Osim toga, Klaus je kao dramaturg i reditelj preveo i postavio nekoliko antičkih drama na scenu: Euripidovog Oresta (1976), Sofoklov komad Na Kolonu (1986), Aristofanovu Lisistratu (1982). Naročito je cenio Seneku. Režirao je i preveo tri Senekine drame: Tijest (1966), Edip (1971) i Fedra (1980). Edipa je modernizovao, izbacivši duge monologe hora i zamenivši ih dijalozima. Režirajući Edipa odlučio je da napiše svoju verziju čuvenog mita. Pri tome se prilikom obrade ponovo oslanjao na Senekinu varijantu. Mit o Edipu i Laju tema je i komada Labdakova loza (1977).

Prva dramska obrada mita o Edipu, Car Edip, datira od Sofokla i prvi put je izvedena na sceni 429. p.n.e. Seneka je u I veku n.e. dao svoju verziju u drami Edip.

Klausova drama Slepac (Blindeman) premijerno je izvedena 1985. godine. Već sam naslov implicitno ukazuje da se radi o Edipu, slepom kralju. No „blindeman“ u 
nizozemskom jeziku ima i značenje dečje igre „ćorava baka“, što dramu pretvara u igru i parodiju. Glavni likovi nakon apokalipse traže „zanimaciju“, „bezighoudinge“ (Klaus, 1985: 21), kao utehu u situaciji kada nema ni pomoći ni spasa. Jedan od preživelih, Franske, predlaže da igraju „Edipa“. Klaus, dakle, koristi tehniku drame u drami, u kojoj mit o Edipu fungira kao meta priča. Svakom liku u drami dodeljena je dvostruka uloga, uloga u realnom životu i mitska uloga.

Podela na činove nije data, ali se kroz igru svetlosti i tame može zaključiti kada počinje komad u komadu. U stvarnoj priči vlada tama, a kada se uključi svetlo počinje dramska igra. Takođe, u nekoliko scena likovi izlaze iz svojih uloga i simuliraju radnju u želji da što verodostojnije prikažu neki događaj. To su scene kada Edip rešava sfinginu zagonetku, kada Kate pada u trans i glumi Pitiju, Apolonovu sveštenicu, kada rekonstruišu smrt Laja.

\section{Intertekstualni elementi u drami Slepac}

U daljem radu analiziraćemo Klausovu obradu drame o Edipu na osnovu teorije intertekstualnosti francuskog teoretičara Žerara Ženeta koju je izložio u studiji Palimpsesti. Književnost na drugom stupnju (Palimpsestes. La Littérature au second degré, 1982) ${ }^{1}$. Nadređeni pojam u Ženetovoj teoriji čini transtekstualnost i obuhvata pet različitih vrsta međutekstualnih odnosa: intertekstualnost, paratekstualnost, metatekstualnost, hipertekstualnost i arhitekstualnost. Za obradu mita o Edipu u drami Slepac za nas je relevantna hipertekstualnost koja se dalje deli na transformaciju i imitaciju. Njihove podvrste date su u dolenavedenoj tabeli (Ženet, 1993: 44):

\begin{tabular}{|l|l|l|l|}
\hline odnos & registar & satiričan & ozbiljan \\
\hline transformacija & parodija & travestija & transpozicija \\
\hline imitacija & pastiš & persiflaža & falsifikat \\
\hline
\end{tabular}

Suštinska razlika između transformacije i imitacije sastoji se u tome što transformacija preoblikuje radnju i likove, dok imitacija podrazumeva oponašanje stila nekog autora. Postoje različiti postupci koju se primenjuju pri transformaciji i imitaciji i mi ćemo u daljem radu ukazati na one koji su relevatni za dramu koju analiziramo. Za naš rad značajna je transpozicija koja može biti: formalna i semantička (tematska). Semantička se dalje deli na pragmatičku i dijegetsku. U drami Slepac možemo uočiti oba postupka: transformaciju i imitaciju. Tema se ne menja, reč je samo o njenoj obradi. Što se tiče stila, možemo ustanoviti da Klaus u pojedinim delovima podražava Senekin stil.

Upoređujući dramatis personae u sve tri drame, Sofoklovoj, Senekinoj i Klausovoj, možemo jasno utvrditi da se Klaus prevashodno oslanjao na Senekinu verziju,

1 Napomena: u radu je korišćen prevod studije na nemački jezik (1993). 
budući da se likovi u ove dve drame gotovo u potpunosti poklapaju. Takođe, početna slova ili slogovi stvarnih imena glavnih protagonista u Klausovoj obradi nedvosmisleno ukazuju na likove iz tragedije. Postupak parodiranja imena Ženet svrstava u dijegetsku transformaciju (1993: 408).

\begin{tabular}{|l|l|l|}
\hline Sofokle & Seneka & Klaus \\
\hline Edip & Edip & Omer (Edip) \\
Jokasta & Jokasta & Jolanda (Jokasta) \\
& Lano (Laj) \\
Kreont & Kreont & Šef (Kreont) \\
Tiresija & Tiresija & Tite (Tiresija) \\
Vodilac Tiresijin & Manto & Kate (Manto) \\
Sveštenik Divov & & \\
Glasnik iz Korinta & Starac iz Korinta & Franske (pastir) \\
Pastir Lajev & Forbas, pastir Lajev & Forten (Forbas ) \\
Glasnik iz dvora & Glasnik & Rosten (rob) \\
Hor staraca Tebanskih & Hor staraca Tebanskih & Mari \\
Kćeri Edipove & & \\
Pratnja careva i caričina & & \\
\hline
\end{tabular}

Osvrnimo se najpre na sve tri verzije kako bismo stekli uvid u promene kojima je podvrgnuta prvobitna priča o caru Edipu. Osim likova možemo ustanoviti da se Klaus i u drugim aspektima oslanjao na Seneku.

Različit karakter Edipa kod Sofokla i Seneke vidljiv je već na samom početku. Za razliku od Sofoklovog Edipa koji je u početku drame ohol i gord, Senekin i Klausov Edip je ophrvan osećajem krivice i lične odgovornosti zbog pošasti koja je zadesila njegov grad.

Sofoklova drama počinje jadikovanjem sveštenika zbog kuge koja vlada u Tebi i on moli Edipa kao prvog među njima za spas, kao što ih je nekada spasao „svirepe pevačice“ (Sofokle, 2001: 334). Kod Seneke Edip je taj koji jadikuje nad sudbinom grada i prima na sebe krivicu. Kod Klausa pastir Franske nas uvodi u priču opisujući užase koji su zadesili grad. On tako preuzima ulogu sveštenika iz Sofoklove drame i tu vidimo da se Klaus poigravao sa obe verzije. Postupak mešanja dva hipoteksta Ženet naziva kontaminacijom (1993: 358-359). No u ovom slučaju nije reč o kontaminaciji, pošto se radi o različitim verzijama iste teme, pa Klausova drama predstavlja hiper-hipertekst, kako Ženet definiše pojavu kada jedan hipertekst privuče naredni hipertekst (1993: 502). Sofoklov Edip bi u tom slučaju bio hipo-hipotekst u odnosu na Klausov.

Laj se kao lik ne pojavljuje kod Sofokla, dok se kod Seneke javlja samo posredno i to preko Kreonta kada ga ovaj posećuje u Hadu i tom prilikom Laj mu otkriva 
svog ubicu, ali ne izlazi na scenu. Klaus zadržava motiv da sam Laj saopštava ime ubice, no za razliku od Senekine varijante, Laj to čini direktno na sceni. Postupak umetanja dodatnih likova koji se ne javljaju u hipotekstu Ženet naziva proširenjem, ekstenzijom (1993: 353).

Dok kod Sofokla prorok Tiresija odmah zna ko je ubica Laja, kod Seneke Tiresija traži da se žrtvuje ovan i gleda u utrobu, ali žrtvovana životinja ne otkriva ko je ubi$\mathrm{ca}$, te je neophodno poslati nekoga u Had. Klaus se poigrava sa ovom scenom kada Tite i Kate iznose glave dva bika kako bi simulirali prinošenje žrtve. Kate stavlja žrtvene životinje na glavu Omera i Jolande govoreći im:

KATE: Vaše Veličanstvo, oboje ste ukaljani,

vi ste žrtvene životinje (Klaus, 1985: 48)².

Ona time predskazuje konačnu sudbinu Omera i Jolande na kraju drame.

Od ostalih likova, u Sofoklovom komadu ne javlja se Manto, Tiresijina kći, već on ima svog vodioca. U Senekinom komadu, a ni u Klausovom ne pojavljuju se Edipove kćeri, dok u Sofoklovoj tragediji one stupaju na pozornicu na kraju komada kada Edip moli Kreonta da se stara o njima.

Kod Sofokla Edip se oslepljuje nakon što pronalazi Jokastu mrtvu i uzima kopču sa njene haljine kojom sebi vadi oči. U Senekinoj i Klausovoj verziji Edip sebi kopa oči pre Jokastinog samoubistva.

\subsection{Imitacija}

Tekst koji oponaša neki drugi tekst Ženet naziva mimotekst (1993: 107). Suština mimoteksta je u imitaciji stila (Ženet, 1993: 109). Imitacija stila uočljiva je već na samom početku drame Slepac. Opis uvodne scene kod Klausa veoma nalikuje na opis s početka Senekine drame. Seneka počinje sumornim prikazom scene: nema zvezda, nebeski svod prekriva gust oblak magle, noć je, u podužem monologu Edip se jada kako je sve zahvatila propast, očevi i majke nose mrtvu decu (v. Seneka, 1888: 8). I Klausova drama sadrži opise užasa: na sceni vlada mrak, sve je pokriveno gustim, crnim dimom, malobrojni preživeli su u stanju raspadanja, „svuda po telu čirevi, plikovi i modrice“ (Klaus, 1985: 7), ljudi se porede sa pečenim hamburgerima (Klaus, 1985: 24), nema hrane da nije zatrovana (Klaus, 1985: 9), zemlja smrdi na mrtve (Klaus, 1985: 27), čuje se zvuk aviona što ukazuje da rat još uvek traje, a jedan je pao u neposrednoj blizini preživelih (Klaus, 1985: 7).

U Senekinoj drami, kada Edip postaje svestan svog greha najpre poželi sam sebi da presudi tako što će se baciti divljim zverima:

Ti Kiteronska šumo,

tolikih prestupnika svedok, pusti na mene

sve svoje divlje zveri, čopor besnih pasa! (Seneka, 1888: 48)

2 Napomena: sve citate sa nizozemskog i nemačkog za potrebe ovog rada preveo: A.Đ. 
Sliku besnog psa preuzima i Klaus:

OMER: Neka me rastrgne krvožedni pas. (Klaus, 1985: 85).

U Sofoklovoj tragediji takvih opisa nema. Upravo po svirepim scenama se i razlikuju Senekine drame od grčkih. Hugo Klaus je, osim Senekom, bio inspirisan i pozorištem okrutnosti (théâtre de la cruauté) francuskog avangardnog dramaturga i pozorišnog reditelja Antonena Artoa (Antonin Artaud).

U Senekinom Edipu Kreont po povratku iz Hada prenosi zagonetnu poruku: kralj je taj koji je „kao nagradu za ubistvo dobio krunu i suprugu sopstvenog oca“ (Seneka, 1888: 33). Slične reči kod Klausa izgovara Jolanda: Ti dobijaš presto, krunu i mene (Klaus, 1985: 39). Pojavu da likovi hipoteksta i hiperteksta zamene uloge ili zastupaju stav onog drugog Ženet naziva supstitucijom (1993: 493)

Takođe, shvativši da je počinio zločin, Senekin Edip ne želi brzu smrt mačem (v. Seneka, 1888: 48), već prstima kida sebi oči. I Klausov Omer prstima izbija oči, prethodno odbivši kuhinjski nož koji mu Mari nudi:

OMER: Moja je krivica prevelika

za smrt u jednoj sekundi (Klaus, 1985: 85-86).

\subsection{Transformacija}

Prilikom transformacije izvornog teksta najčešći postupak koji se primenjuje je transdijegetizacija, promena dijegeze (up. Ženet, 1993: 404-406). Pod dijegezom se podrazumeva svet u kome junaci žive. Promena dijegeze nastaje kada se radnja premešta u drugu epohu, na drugo mesto. Ovde je reč o semantičkoj transformaciji, koja sa sobom vuče i pragmatičku transformaciju, promenu radnje, što je i logično, jer moderan Edip se ponaša drugačije od Edipa iz antičkog doba. Ženet navodi da je u ovom slučaju namera autora da približi dijegezu publici, da prikaže njoj blizak svet, tako da je ovde reč i o postupku približavanja, odn. aproksimacije (1993: 416). Taj postupak Ženet naziva još i dijegetska modernizacija (1993: 423).

Drama Slepac namenjena je savremenoj publici, samim tim promena dijegeze je neophodna. Klaus je dramu obojio lokalnom notom, ne samo time što se pominju toponimi vezani za grad Gent, već svojevrsnom couleur locale doprinosi i to što je drama pisana na gentskom, odn. istočno-flamanskom dijalektu. Četvrt Gentbrihe, veštačko jezero Vatersportban, katedrala Svetog Bava, raskršće kraj sela Zvejnarde, trg Kornmarkt, Flamansko pozorište, zgrade Belgijske Radio-televizije BRT i Mekdonaldsa žive još samo u sećanju likova na sceni s obzirom da su zbrisana sa lica zemlje. Nisu nestali samo određeni delovi grada, već i čitava kulturna baština, poput čuvenog gentskog oltara braće Van Ajk Mistično jagnje (Het Lam Gods).

Klausova namera je bila da napiše društveno-angažovanu dramu i podvrgne kritici političke okolnosti s kraja XX veka. Drama je nastala u jeku Hladnog rata, kada je strah od atomskog sukoba Sjedinjenih Američkih Država i Sovjetskog Saveza bio sveprisutan. I u slučaju nuklearnog napada zavladao bi opšti pomor kao i 
u slučaju kuge. Tako Klaus povlači paralelu između kuge koja hara Tebom i zaraze koja bi se proširila u slučaju atomskog rata. Klaus dalje upozorava na posledice koje može prouzrokovati atomski rat: jedna od njih je i nuklearna zima koja bi nastupila usled klimatskih promena izazvanih ogromnim zagađenjem atmosfere nakon nuklearne eksplozije ${ }^{3}$. U drami još uvek nije zavladala nuklearna zima, jer se komad odigrava neposredno posle atomskog napada. Nuklearna zima se javlja kao pretnja (Blondeel, 2014: 32). Česte su upadice u komadu gde se pominju zima i hladnoća:

JOLANDA: Postaje hladno, zar ne osećate? (Klaus, 1985: 20);

KATE: Postaje hladno ili se to meni čini?

ŠEF: Čini se da će biti sve hladnije (Klaus, 1985: 52).

Klaus ne propušta priliku da se ne osvrne i na nedavnu belgijsku prošlost vezanu za bivšu koloniju Kongo. U potrazi za zanimacijom, Jolanda bi najradije da čuje neki mastan vic o Kongu. Šef koji je bio u Kongu i kao padobranac spašavao belce iz rata koji je izbio nakon proglašenja nezavisnosti, ne želi dalje da sluša viceve koje kvalifikuje kao neukusne i glupe (Klaus, 1985: 22).

\subsubsection{Transformacija radnje}

Po Ženetu, pri transformaciji radnje uvek je reč o izvesnoj korekturi (1993: 426) koja je podvrsta pragmatičke transformacije.

U verzijama Sofokla i Seneke Edip je pošteđen bolesti koja hara i koja je zahvatila njegov narod. Kod Klausa sve likove osim Šefa nešto muči: Tite je slabovid (Klaus, 1985: 26), Vorten ima šećernu bolest (Klaus, 1985: 8), Kate „se ne oseća dobro“ (Klaus, 1985: 9), Lano, Tite i Omer se žale na probavu (Klaus, 1985: 9), Omera uz to bole gležnjevi (Klaus, 1985: 76) i ima visok pritisak (Klaus, 1985: 15).

U Klausovoj verziji umesto sfinge svi likovi uglas postavljaju Omeru zagonetku, koju on sasvim slučajno rešava, i to tako što ostali pogrešno interpretiraju njegovu zbunjenost:

OMER: Kako glasi pitanje? (očajan)

SVI: (šapućući naglas) Šta hoda ujutru na četiri

noge,

u podne na dve, uveče na tri?

OMER: Treba mi celu noć da razmislim.

SVI: (naglas) Šta hoda (itd.) (Omer odlazi, ali ga hvataju za odoru od padobrana i vuku ga nazad, padobran pada na pod)

OMER: (viče) Ali ja, ja...

SVI: (radosno kliču) Pogodio je.

Pravo u metu!

3 Do ovog zaključka došla je grupa naučnika okupljena oko Karla Sagana (v. https://www.britannica.com/science/ nuclear-winter). 
Da, to si ti!

Ja, rekao je, i to je tačno.

Ja, rekao je, što će reći: čovek!

OMER: Ali ja nisam više čovek [...]

Mi smo mrtvaci koji hodaju [...]

kad smo uopšte bili ljudi (Klaus, 1985: 37-38).

U Sofoklovoj i Senekinoj verziji sfinga umire nakon što Edip reši zagonetku. Kod Seneke, u jednoj sceni Edip uzvikuje da se pepeo sfinge sveti i želi da sruši carstvo (v. Seneka, 1888: 11). Klaus reinterpretira tu scenu i ide korak dalje: sfinga, koja je u Klausovoj drami predstavljena kao kokpit aviona, još uvek daje znake života, ispuštajući zvuke koje Omer pokušava da utiša jer će „ponovo da nosi rakete koje će da spaljuju ljude“ (Klaus, 1985: 39). Međutim, Šef je taj koji najzad ućutkuje sfingu. U kokpitu se nalazi kaseta sa nerazumljivim tehničkim izrazima, među kojima je i šifra „Blind king“ (Klaus, 1985: 37), što predstavlja zagonetku, a ujedno i proročanstvo. Promena objekta (u našem slučaju sfinga-kokpit) takođe spada u pragmatičku transformaciju u Ženetovoj teoriji intertekstualnosti (1993: 429).

Još jedan postupak koji definiše Ženet, a srećemo ga u Klausovoj drami je motivacija (1993: 440). Naime, kralj Polib, za koga Edip misli da mu je otac, umire u snu od infarkta (Klaus, 1985: 71). Kod Seneke se samo pominje da je Polib umro u snu (Seneka, 1888: 40), dok Klaus navodi i uzrok. U ovom smislu motivacija predstavlja dodatni motiv koji se ne javlja u izvornom tekstu. Obrnuto, ukoliko hipertekst ne navodi motiv spomenut u hipotekstu, reč je demotivaciji (Ženet, 1993: 440).

Klaus unosi još jednu izmenu u odnosu na mitsku priču: Jokasta od početka zna ko je Edip. Ona je Edipa odmah prepoznala po stopalima, čim je ušao u palatu. Kasnije mu se ispoveda:

JOLANDA: Nije bila tvoja krivica. Nikada. Ja sam kriva [...]

Ja sam znala za zlo, ti ne (Klaus, 1985: 91).

U Klausovoj interpretaciji Jokasta je očigledno bila vođena drugim motivima prilikom udaje za Edipa nego što je to u originalnoj verziji. Ovu pojavu Ženet definiše kao transmotivacija (1993: 439).

Takođe, u Klausovoj obradi Edip ubija samo slugu Rostena, ne i kralja. Laj uspeva da pobegne, ali ga pljačkaši sustižu i ubijaju. Omerova žrtva se time obesmišljava i, kako smatra De Vos (1985: 449), čitava tragedija se pretvara u farsu, jer Omerovo žrtvovanje ne donosi spas ni njemu ni zajednici. Za De Vosa ovaj komad je mešavina tragedije i pučke igre, jer je drama začinjena i plitkim humorom, a to se ogleda i u kostimima. Jolanda nosi srebrni papirni plašt koji menja boje u zavisnosti od svetlosnih efekata na sceni, potom nosi nešto nalik na crvenu periku, napadno je našminkana, a Omer pronalazi padobran, koga ogrće kao kraljevsku odoru, čime se kombinuju velelepnost i jeftina imitacija (v. De Vos, 1985: 449). I Fredi Dekreus primećuje da se u ovoj drami brišu granice između tradicionalnih kategorija tragič- 
nog i komičnog. S jedne strane, smatra Dekreus, gledalac je suočen sa ozbiljnošću postapokaliptičnog pejzaža, dok s druge strane iluziju tragičnosti razbija forma grotesknog i ciničnog pozorišta (v. Dekreus 1995: 15).

\subsubsection{Transformacija likova}

Kada je reč o transformaciji likova, Ženet navodi da se uvek radi o psihološkoj transformaciji koju naziva i transmotivacija. U modernoj drami nemamo jednodimenzionalne likove kao $\mathrm{u}$ antičkim, moderna drama zahteva kompleksne ličnosti. Pored toga, određeni lik može dobiti ili izgubiti na vrednosti u odnosu na lik iz originalnog teksta. Tu pojavu Ženet naziva transvalorizacija (1993: 453) i dalje je deli na valorizaciju (1993: 464), devalorizaciju (1993: 477) i supstituciju (1993: 493).

Pri raspodeli uloga za predstavu o Edipu karakterne osobine likova u stvarnoj priči odgovaraju ulogama koje preuzimaju u dramskoj igri. Premda glume Edipa i Kreonta, uloge Omera i Šefa su u biti zamenjene. Šef se nameće kao vođa, te je shodno tome i dobio nadimak. Za razliku od ostalih likova, jedino on se ne pominje po imenu. Šef odlučuje o raspodeli hrane, koju potom deli Rosten, njegov sin. Stoga je i uloga roba iz mita dodeljena Rostenu. Uloga koju Šef uzima za sebe u potpunosti odgovara njegovom karakteru. Njegova sušta suprotnost je Omer, koji nema ambicija da bude vođa. Čak ni u igri nije u stanju da se nametne kao vladar i tu ulogu prepušta Šefu. To je vidljivo u nekoliko scena u drami, npr. kada Omer šalje Šefa u podzemni svet kako bi pitao Laja za savet, on mu kaže:

OMER: Samo idi, ja ću paziti na tvoju republiku.

Možeš da imaš poverenja u mene (Klaus, 1985: 53).

Omer, dakle, sam priznaje da je njegova uloga beznačajnija od Šefove. Poređenja radi, kod Seneke, u trenutku kada se bira ko će da siđe u Had da bi se sreo sa Lajom, Edip predlaže Kreonta koji je „po činu i dostojanstvu njemu najbliži“ (Seneka, 1888: 23). Osim toga, u Klausovoj reinterpretaciji Šef je ugasio kokpit koji predstavlja sfingu. Drugim rečima on ju je „ubio“, što opet umanjuje Omerov značaj. Ni ostali likovi ne priznaju Omera za vođu. Tako Jolanda u jednoj sceni pita Omera:

JOLANDA: [...] jesi li sluga ili kralj ili nešto između? (Klaus, 1985: 34, 35).

Takođe, i Tite se obraća Omeru:

TITE: Drugo, ti ovde nisi šef. On je. Zar ne, Šefe?

ŠEF: Vi ste me izabrali (Klaus, 1985: 19).

Ovde je u pitanju inverzija mita, po kome je tebanski narod izabrao Edipa za kralja, nakon što je rešio sfinginu zagonetku. Tu inverziju, zamenu uloga, Ženet naziva supstitucijom. Pored toga, Šefu, tj. Kreontu, se daje veća važnost nego u originalnoj verziji, što Ženet naziva valorizacijom, dok je u Omerovom, odn. Edipovom slučaju reč o devalorizaciji, jer je njegova uloga umanjena. 
I u Sofoklovoj i Senekinoj verziji Jokasta prezire muža jer joj je oteo dete, dok Klaus taj motiv začinjava još jednim podatkom iz Lajovog života i reinterpertira ga. Naime, Laj ima homoerotske sklonosti. Biskup ih je naveo da se venčaju, ali Laj se nije promenio, zbog čega je biskup prorekao ubistvo oca od strane sina:

JOLANDA: [...] I biskup je rekao: 'Veličanstvo, najbolje će biti

da se venčate, proći će vas, videćete.'

I venčao se sa mnom, ali nije prošlo.

I biskup reče: 'Ako je tako sire,

da nećete da se promenite, onda proričem

najgore, dobićete sina i taj sin

će oca glave koštati' (Klaus, 1985: 68).

Sofokle i Seneka ne pominju predistoriju Laja. Naime, boraveći na dvoru kralja Pelopa, Laj je oteo njegovog sina Hrisipa i odveo ga sa sobom u Tebu. Pelop ga je prokleo da nema potomaka ili da pogine od ruke vlastitog sina (Kun, 2003: 473). I ovde se radi o dodatnoj motivaciji (Ženet, 1993: 439) koju dramski predlošci kojima se Klaus koristio ne pominju.

Lano takođe bira ulogu za sebe. On pokazuje sklonost ka travestiranju, a s obzirom na predistoriju Laja, on je najprikladniji za tu ulogu. On bi zapravo najradije da igra kraljicu:

LANO: [...] To je zato što ste svi malograđani, ali ja bih najradije... kraljicu... (Klaus, 1985: 25).

Klaus na taj način kritikuje provincijalizam svojih sunarodnika, što je jedno od bitnih obeležja njegovog stvaralaštva.

Zbog svoje slabovidosti Tite smatra da je on prava osoba za ulogu slepog proroka Tiresije. Tiresija je „slep, ali njegov duh vidi“ (Klaus, 1985: 46) i on tumači poruke koje bogovi šalju. Poput Tiresije, i Tite predskazuje nesreću:

TITE: Au, au, moje svračje oči... (Klaus, 1985: 13).

Simbolika svrake u zapadnoevropskom folkloru uglavnom je negativna, pa se i sama pojava te ptice tumači kao zloslutni znak (Chevalier/Gheerbrant, 1989: 672).

Jedino Mari nema svog ekvivalenta u Senekinoj drami. Takođe, ona se drži po strani i ne učestvuje u igri u kojoj ostali glume. Mari zapravo ispunjava funkciju hora u antičkoj drami. U prvom pojavljivanju Mari proročki nagoveštava sudbinu Laja i Edipa, dok se priseća razgovora sa ćerkom odmah nakon nuklearnog napada:

MARI: 'Mama', povikala je, 'moje oči!' - 'Tvoja je krivica, Marijanice', kažem ja, 'nisi smela da se šetaš ulicom.' (Klaus, 1985: 13). 
Ovaj razgovor kao da su vodili Laj i Edip, Edip koji će oslepeti i Laj koji prekorava Edipa što mu se preprečio na putu.

\subsubsection{Formalna transformacija}

U formalnu transformaciju polaznog teksta spadaju, prema Ženetu, redukcija i ekstenzija (1993: 313-314). Ekstenzija obuhvata uvođenje dodatnog lika u novonastali tekst, u ovom slučaju Mari, kao i tematsko proširenje. Dodavanje teme koje nema u izvornom tekstu Ženet naziva još i amplifikacijom (1993: 363). Klaus inkorporira hrišćansku tematiku u osnovnu radnju i u tu svrhu uvodi lik Mari. Po tumačenju Fredija Dekreusa (prema Blondeel 2014: 41) ona je predstavnik katolicizma u komadu. Već njeno ime je poistovećuje sa devicom Marijom, a pored toga izgubila je i ćerku, što ukazuje na Mariju i Isusa. Promenu pola u hipertekstu Ženet ubraja u dijegetsku transformaciju (1993: 406). Dekreus dalje interpretira Marino odbijanje da učestvuje u pozorišnoj predstavi „Edip“ kao odbijanje da igra „u paganskoj igri“ (citirano prema Blondeel, 2014: 41). Takođe, on primećuje da se ona meša u igru jedino kada čuje religiozne reči ili reči koje bude njen majčinski instinkt (v. Blondeel, 2014: 41).

U Edipu XX veka antički bogovi su zamenjeni hrišćanskim bogom. Klaus kritikuje katolicizam, tako što krivicu za nesreću koja je snašla protagoniste ove drame prebacuje upravo na hrišćanskog boga:

TITE: Čija je onda krivica?

MARI: Boga i njegovih zapovesti. (Klaus, 1985: 62)

Obraćajući se mrtvoj kćeri, Mari još jednom proziva boga:

MARI: Marijanice, zadovoljan je

onaj okrutni tip

jer si mrtva na mom krilu ležala (Klaus, 1985: 49).

Ovde se jasno aludira na sliku Isusa na Marijinom krilu. Slika Marije i Isusa u krilu često se priziva i u scenama sa Jolandom i Omerom.

Omer takođe optužuje boga za zlu kob koja ih je zadesila:

OMER: Bog je svirep. Mi umiremo, a on zeva (Klaus, 1985: 72).

Bog kao da se povukao i prepustio čoveku da sam upravlja svojom sudbinom. U završnoj sceni Omer pokušava da pobegne i govori da ide „tamo gde nema ničega, ni prašine, ni boje, ničega“ (Klaus, 1985: 94). Krivicu u svetu bez boga snosi, zapravo, čovek. Jer čovek je taj koji je izazvao atomski rat. Kod Sofokla i Seneke traga se za krivcem, zbog koga su bogovi poslali kugu kao kaznu, dok Klausovi likovi tragaju za utehom i smislom nakon nesreće koja ih je zadesila. Igrajući Edipa oni zapravo traže odgovor na pitanje ko je krivac za katastrofu. U antičkim dramama krivica je, 
zapravo, sudbina, fatum, na koju čovek ne može da utiče. Na kraju Senekine drame hor rekapitulira:

Sa silama sudbine rvati se uzalud je! [...]

fatum upravlja svime (Seneka, 1888: 50).

Sudbina je to uredila, nije naša krivica (Seneka, 1888: 52), kaže i Jokasta.

Erotske aluzije takođe predstavljaju tematsko proširenje, amplifikaciju. Kate nazivaju „kurvicom“, „hoerejong“ (Klaus, 1985: 11, 18). Ona najpre ima odnos sa Rostenom, što se ne prikazuje eksplicitno na sceni, već se to dešava iza pozornice, a publika čuje glasove koji upućuju na snošaj:

Kate se penje do niše, Rosten joj prilazi, uzima je za ruku, uvlači unutra [...]

čuju se jecaji i uzdasi Katini [...]

zvuk Katinog orgazma (Klaus, 1985: 16-17).

Kate potom zavodi Franskea, a na kraju komada pokušava da zavede i Omera, ali joj ne polazi za rukom, jer je on odbija.

Erotska konotacija prisutna je i u dijalozima Jolande i Omera:

OMER: Hoćeš da kažeš da nisam dasa?

Ne sećaš se više ničega? (Klaus, 1985: 35)

U drugoj sceni Jolanda se obraća Omeru lascivnim insinuacijama poput sledeće:

JOLANDA: Zar nećeš više sa mnom... (Klaus, 1985: 91)

Na kraju komada Omer je, po svemu sudeći, zaista sebe oslepeo. Takav zaključak može se izvesti na osnovu toga što on tumara na bini i opipava stvari oko sebe. Takođe, slutimo da Jolanda zaista umire na kraju predstave, jer od trenutka kada je odigrala smrt Jokaste, ostala je da leži na sceni i više se nije podigla. Čini se da su se stvarna priča i odigrana priča na kraju stopile u jednu.

\section{Zaključak}

Drama Slepac je, s jedne strane, literarna igra, izazov za autora da snagom sopstvene imaginacije kreativno pristupi već postojećem izvoru, u ovom slučaju mitu o Edipu. S druge strane, reč je o politički angažovanom komadu koji se bavi ozbiljnim izazovima s kojima se svet suočavao u toku Hladnog rata. Hugo Klaus kroz igru i parodiju ukazuje na rizike i opasnosti koje sa sobom nosi neprestana trka u nuklearnom naoružanju. Autor poseže za mitom tražeći u njemu opšteljudsko i univerzalno, a iznad svega odgovor na pitanje o krajnjem ishodu čovekove sudbine u svetu bez boga, u svetu dirigovanom ljudskom palicom. Primenjujući teoriju intertekstualnosti 
Žerara Ženeta, ustanovili smo niz postupaka koje je Klaus koristio prilikom adaptacije starogrčkog mita o Edipu. Jedan od tih postupaka je premeštanje radnje u nov, publici prepoznatljiv kontekst, koji Ženet definiše kao transdijegetizaciju. Promena dijegeze za sobom povlači intervencije u samoj radnji, kao i u motivaciji likova koji tu radnju pokreću. Transformacija radnje uočljiva je u činjenici da Edip nije ubica Laja, a transmotivacija, tj. promena motivacije, u Jokastinom svesnom upuštanju u odnose sa sopstvenim sinom. Od ostalih postupaka koje Ženet definiše, u Klausovom komadu srećemo supstituciju, zamenu uloga, u slučaju Edipa i Kreonta. Na nju se nadovezuju valorizacija i devalorizacija, vidljive u činjenici da je Kreontu dodeljena značajnija uloga od one koju ima u izvornom mitu, dok je s druge strane uloga glavnog lika u drami, Edipa, znatno umanjena. Kritika religije i s njom u vezi izražen ateizam i nihilizam, prisutni u drami Slepac, spadaju u Ženetovoj klasifikaciji u amplifikaciju, tematsko proširenje. U tu svrhu javlja se i ekstenzija, umetanje dodatnog lika, Mari, koja reprezentuje hrišćansku doktrinu. Kada je reč o stilu, primetno je da Klaus u izvesnim delovima oponaša Seneku, što se očituje u prikazu užasavajućih scena kao i preuzimanju Senekinih metafora. Komad Slepac je tipičan za razumevanje Klausa kao pisca: autor meša tragično, uzvišeno i klasično sa banalnim, burlesknim i opscenim. Gotovo sve konstantne teme njegovog stvaralaštva obrađene su u ovoj drami: prezir prema ocu, seksualnost i erotika, osećaj krivice, kritika katoličanstva, kritika flamanskog provincijalizma, društvene i političke okolnosti u Flandriji i svetu u drugoj polovini XX veka.

Napomena: rad je izložen u vidu usmenog saopštenja na simpozijumu „Antička drama“ održanog 22-23.10.2016. na Filološkom fakultetu u Beogradu.

\section{Literatura}

Blondeel, P. (2014). De sporen van de bloedhond. De senecaanse Oedipus in het oeuvre van Hugo Claus. Dostupno preko: http://lib.ugent.be/fulltxt/RUG01/002/162/753/ RUG01-002162753_2014_0001_AC.pdf [18.12. 2019]

Chevalier, J., Gheerbrant, A. (1989). Rječnik simbola. Zagreb: Nakladni zavod Matice hrvatske.

Claus, H. (1985). Blindeman. Amsterdam: De Bezige Bij.

Claes, P. (2000). De gulden tak. Antieke mythe en moderne literatuur. Amsterdam: De Bezige Bij.

Claes, P. (1984). De mot zit in de mythe. Hugo Claus en de oudheid. Amsterdam: De Bezige Bij.

Decreus, F. (1995). Oedipus en de sfinks in het toneel van Hugo Claus. Enkele recente producties. Documenta, 13(1), 3-29.

DeVos, J.(1985). Claus, Oedipus und kein Ende. Onserfdeel, jaargang 28,449-450. Dostupno preko: http://www.dbnl.org/tekst/_ons003198501_01/_ons003198501_01_0110. php [18. 12. 2019]

Genette, G. (1993). Palimpseste. Die Literatur auf zweiter Stufe. Frankfurt am Main: Suhrkamp.

Kun, N. A. (2003). Legende i mitovi stare Grčke. Beograd: Dečja knjiga. 
Novaković-Lopušina, J. (2005). Leksikon holandske i flamanske književnosti. Beograd: Partenon.

Seneka, L. A. (1888/1889). Ödipus. Regensburg: Stadtamhof, Druck J. \& K. Mayr. Sofokle (2001). Car Edip. U Grčke tragedije (pp. 331-396). Beograd: Dereta.

\section{Aleksandar S. Đokanović}

Summary

\section{TRANSFORMATION OF THE MYTH OF OEDIPUS IN HUGO CLAUS' PLAY THE BLIND MAN}

The myth of Oedipus remains an inexhaustible source of inspiration in the $20^{\text {th }}$ century. The Flemish writer Hugo Claus gave his version of the famous myth in in the play The Blind Man (Blindeman) in 1985. It is a parody of Seneca's Oedipus, on which Claus relied in writing his own version. The play Blindeman is set in the $20^{\text {th }}$ century. The story takes place in Ghent after a nuclear disaster. It is a reinterpretation of the original myth, in which the city of Thebes is affected by the plague, while in the play Blindeman the city of Ghent is hit by the plague of the modern age caused by a nuclear war. Regarding the composition of the drama, Claus uses the technique of a play-within-a-play. The survivors perform the piece „Oedipus“ and in that way Claus draws a parallel between the story in the present and the heroes of the aforementioned myth. Each character of the play has their counterpart in the mythic story and plays a double role. Their names are recognizable by the fact that they begin with the same letter or syllable as in the original myth: Omer, Yolande, Lannoo, Tiete. During the entire piece, Claus plays with the myth. For example, in his adaptation Jocasta knows from the very beginning that Oedipus is her son. The theoretical background of the article is based on Gerard Genette's theory of intertextuality.

\section{Key words:}

myth, Oedipus, patricide, incest, blindness, plague, nuclear disaster, theory of intertextuality, Genette 